\title{
Poetics of Space and Its Association with Human Soul in Brian Dillon's In the Dark Room
}

\author{
Hassan Abootalebi ${ }^{1}$ \& Alireza Kargar ${ }^{2}$ \\ ${ }^{1}$ PhD student of English Language and Literature, Kharazmi University, Tehran, Iran. \\ Email:abootalebi2010@gmail.com \\ ${ }^{2} M . A$ in English Language and Literature, Lorestan University, Khorramabad, Iran. \\ Email: alirezakargar1984@gmail.com
}

\begin{abstract}
The present paper intends to analyze and put under scrutiny Brian Dillon's memoir In the Dark Room (2005) in the light of Gaston Bachelard's theories of house as an intimate space explicated and expounded on in his magnum opus The Poetics of Space (1964). Since Bachelard's ideas are often associated with phenomenology which accentuates the significance of the manner in which phenomena appear to us and are given meaning, the house and objects in it as a place of intimacy are of paramount importance to him. The spaces along with objects are not merely possessions which can be lived in or owned by individuals, but rather they express and suggest human emotions and human soul. They also have the power to transport us back into a distant past and evoke deeply buried memories and feelings. The house, says Bachelard, protects both daydreaming and the dreamer and allows one to dream in peace. Moreover, it provides a restful place in which imagination and thought are both stimulated. The title-mentioned work can be investigated in the light of Gaston Bachelard's theories to provide proof for the above claim. The narrator of In the Dark Room is surrounded with objects and places which are capable of taking him back to the past arousing his interest and making him conjure up bygone days. Not only does the house function as a metaphor for evoking memories, but also the street and the place in which Dillon's mother was hospitalized are accentuated. Hence, in the subsequent sections of the current paper, first phenomenology will be defined and elaborated on, then Brian Dillon's selected work will be scrutinized based on Gaston Bachelard's house-related theories and notions in order to demonstrate the association of the house and its objects with human soul and imagination.
\end{abstract}

KEYWORDS: Gaston Bachelard, Poetics of Space, Brian Dillon, In the Dark Room, phenomenology

Memories of the outside world will never have the same tonality as those of home, by recalling these memories, we add to our store of dreams; we are never real historians, but always near poets, and our emotion is perhaps nothing but an expression of a poetry that was lost.

(Gaston Bachelard, The Poetics of Space)

\section{Introduction}

Both a philosopher and a literary analyst, Gaston Bachelard was one of the major figures in intellectual history. He was highly interested in the concept of epistemology; the branch of philosophy which studies the nature of knowledge, in particular its foundations, scope and validity. He also introduced some significant concepts in the realm of philosophy of science which deal with the progress of science and its possible obstacles. His later work was, however, associated with phenomenology. Hence, to begin with, it might be helpful to provide a concise introduction to, and definition of, the word phenomenology. As a philosophical movement,

(c) AesthetixMS 2020. This Open Access article is published under a Creative Commons Attribution Non-Commercial 4.o International License (http://creativecommons.org/licenses/by-nc/4.o/), which permits non-commercial re-use, distribution, and reproduction in any medium, provided the original work is properly cited. For citation use the DOI. For commercial re-use, please contact editor@rupkatha.com. 
phenomenology is distinguished by a "concentration on descriptions of experience" which unconceal the meanings objects possess for "human beings prior to theoretical interpretation" (Payne \& Barbera 2010, p. 125). It pays much attention to the "perceiver's vital and central role in determining meaning." The main concern of philosophical inquiry is, however, not the objects in the world that are comprehensible "through the senses" but rather, "a priori contents of our consciousness." The method, therefore, requires a "close inspection of mental and intellectual states and processes." By doing so, it is possible to reveal the "underlying nature of consciousness and phenomena" around us. As far as literature and literary theory are concerned, the phenomenologist's critical approach involves an "entry to, and investigation of, the underlying nature and essence" of a literary work under examination and scrutiny and thus a "kind of access to the author's consciousness" (p. 126).

As an important philosophical approach expounded by Edmund Husserl, phenomenology, however, rejects "the Cartesian duality of subject and object." It rather presupposes "an internal relationship between the subject and the object." The objects in the world gain identity and even existence "when they are observed or experienced." What we indeed encounter are not objects but 'phenomena' around us. It seems as if these phenomena are "the synthesis of human consciousness that experiences them." Husserl, indeed, set out to analyize "human consciousnessthat is to describe the concrete lebenswelt (lived world)" as this is experienced "independently of any prior suppositions" whether these suppositions come from philosophy or from "common sense." Furthermore, he suggested that consciousness is a "unified intentional act"; that is, it is always "directed to an object". Put it another way, to be "conscious is always to be conscious of something" (Abrams 2005, p. 260). Phenomenology, as a result, pays much attention to the "nature of lived experience" dealing in a fundamental way with "our status as beings whose existence is enabled and determined by particular physical and cultural conditions." It is also based on the premise that experience possesses a "questioning character." That is, experience is not apprehending a "pre-formed content." It is instead a "form of prospection or enquiry" (Cazeaux 2001, p. 66).

Phenomenology, Morat (2000) argues, can be best understood as a "radical, anti-traditional style of philosophizing" which highlights the effort to "get to the truth of matters." In other words, to "describe phenomena, in the broadest sense as whatever appears in the manner in which it appears; that is, as it manifests itself to consciousness, to the experiencer." It also needs, says Morat, to "describe things as they appear to consciousness." Put it another way, the way "problems, things, and events are approached must involve taking their manner of appearance to consciousness into consideration" (pp. 4,6). Phenomenology, therefore:

maintains that the categories with which philosophy has divided up experience in the past are not adequate to experience; they break up continuous experience into things, and let that sense of a lived point of contact between mind and reality slip away. Thus, new perspectives on experience are offered which take the intertwined nature of mind and reality as their starting point. (Cazeaux 2001, p. 66).

However, phenomenology is closely related to hermeneutics. Hermeneutics, originally defined, is "the art of understanding and interpreting historical texts." Broadly speaking, three phases have been recognized and distinguished in the history of hermeneutics: 'theological', 'romantic', and 'phenomenological'. While the first two are mainly concerned with recovering "the true meaning a text would have had in the age it was written" liberated from the "mediation and distortion" brought about by "translation and passage of time", the last one, however, recognizes the fact that the hermeneutic is "herself rooted in history." Consequently, any interpretation is always 
"mediated by the historically constructed assumptions and expectations which constitute her practice as an hermenut." It is this recognition and appreciation of the "perspectival nature of historical, textual interpretation" which makes recent hermeneutics 'phenomenological'(Cazeaux 2001, p. 65).

The term phenomenological criticism is also worth mentioning here as it is often applied to "the theory and practice of the Geneva school of critics." These critics consider every work of 'literature' as a "fictional world" which is made out of the "lebenswelt of its author" and reflects the "author's unique mode of consciousness." A subjective approach to literature, "this criticism is opposed to the objective approach of formalism" and its roots date back to the "nineteenth century' to that kind of "romantic expressive criticism" which used to think of a work of art as the "revelation of the personality of its author, and also proposed that the awareness of this personality is the chief aim and value of reading literature." With the passage of time, however, Geneva critics "assimilated a number of concepts and methods of Husserl, Heidegger, and other phenomenologists” (Abrams 2005, p. 261).

The Poetics of Space (1964) written in the last stages of Gaston Bachelard's philosophical career, focuses on the house, its interior places and outer context applying phenomenology to architecture. The book deals fundamentally with the principle that "thought and experience emerge or unfold themselves from their surrounding, defining conditions." His theme is, however, the house, or home: "the domain in which we spend our time" and where "we have the most intimate experiences" (Bachelard 1964, p. 73). Bachelard considers "objects and spaces in the house not being detached from the man but experienced and inhabited by him"(Nojoumian 2006, p. 2). The house is, Bachelard argues further, "made of memories and experiences and its different parts arouse different sensations and bring up an intimate experience of living" (Bachelard 1964, p. 177). As a result, the house, where we are born in, is not merely "an embodiment of home", but an embodiment of 'dreams'. Every space in the house, Bachelard maintains, is a "resting-place for daydreaming"(p. 51). Bachelard even goes further by claiming that the house is the main place for man to take shelter and remain immune to dangers of any kind:

In the life of a man, the house thrusts aside contingencies, its councils of continuity are unceasing. Without it, man would be a dispersed being. It maintains him through the storms of the heavens and through those of life. It is body and soul. It is the human being's first world. Before he is cast into the world, as claimed by certain hasty metaphysics, man is laid in the cradle of the house. And always in our dreams, the house is a large cradle. A concrete metaphysics cannot neglect this fact, this simple fact, all the more, since this fact is a value, an important value, to which we return in our daydreaming. Being is already a value. Life begins well, it begins enclosed, protected, all warm in the bosom of the house. (p. 43)

However, the chief benefit of the house, says Bachelard (1964), is that the house "shelters daydreaming." What sanction "human valuse" are not, he suggests, "thought and experience" but those belonging to "daydreaming' which "mark humanity in its depths" (p. 42). He also introduces his concept of topoanalysis as the systematic psychological studying of the sites of our intimate lives. The house, the most intimate of all spaces protects the daydreamer and therefore understanding the house is for Bachelard a way to understand the soul. We are supposed to think of a house, says Bachelard, not as an 'object' on which we can "make our judgments and daydreams react." Neither is it a question of describing it or 'enumerating' its different qualities and features. We, he claims, need to go beyond descriptive features either 'subjective' or 
'objective' and consider the house "our corner of the world, our first universe, a real cosmos in every sense of the word” (p. 4).

\section{Discussion}

In his highly polemical work The Poetics of Space (1964), Gaston Bachelard advanced the idea that houses and rooms could be viewed as "tools for analysis of the human soul." The house is, he claims, "one of the greatest powers of integration for thoughts, memories and dreams of mankind" (p. 1). Brian Dillon, before leaving the house for the last time while standing in the middle of the sitting room, recalls more than anything else:

a sense of what it felt like to move about in that medium. I remember the quality of light in a bedroom at dawn; the sudden acoustic shift that occurred when I opened a bathroom door...Imagine the house, and you picture a passage from empty space to tangible things, from the feeling of moving in an abstract territory to the shock of rediscovering the objects it contains...But to see that house empty...is to catch sight of a less tangible image: the ghost of ourselves wandering from room to room like a bad student of classical rhetoric, failing to find the proper places to deposit his lesson. (Dillon 2005, p. 20)

What Dillon calls to his mind is the picture of the house "in all its familiarity" instead of a "purely abstract sequence" he is enabled to "replay' there in his mind. The house, according to the "teachers of the art of memory", is noted for being a "better repository of memories than an imagined one" (p. 20). Different rooms and spaces remind him of both near and distant memories particularly the centre of the house where a "deep and thrillingly perpendicular shaft dug into the middle of my imaginative world" (p. 23). Thus, he transforms "the space into a safely cartographic set of images" which he will take with him to his new house. There, he hopes, they will be "submerged by new experience, overlain to the point of illegibility" (p. 24).

The house is, Bachelard (1964) contends, "made of memories and experiences and its different parts arouse different sensations and bring up an intimate experience of living." For him, the house serves as "the portal to metaphors of imagination." A high value is placed on each single room and object. The significance of every nook and cranny is, therefore, explored so that they will become "symbols of solitude for the imagination" (p. 2). This is the case with Brian Dillon when he contemplates his family house. The house is instrumental in the history he tries to retell his reader, and functions as a pathway to his imagination and invokes images of the past:

The vertigo that overcame me in my final minutes before leaving the house has its origin in a sense that each room is a separate passage into the past. ( In her diary, Virginia Woolf makes this link between memory and space; she describes how, behind the present which each of her characters inhabits, a profound tunneling is going on: an unending excavation of the self.) But numerous chambers of experience come to occupy bewilderingly, the same space. In my memory I can stand at a specific spot in the house and feel myself thrust into an endless series of adjacent moments. (Dillon 2005, p. 30)

Later in the work, the house is compared to a "Chinese box" in which each "newly discovered receptacle" is the same size as those that contained it. The significance attached to each of them seems to be equal, no one of them having priority over others. Each, however, wants to "adopt the same pose" (p. 30). Consequently, everyone who ever moved in each room seems as if is 'jostling' for position at the centre of his recollection in order to claim priority in his memory. But to decide which of them are worth recalling first and most is not possible. The 'Chinese box' allows Brian 
Dillon to stand in a specific place and feel himself being transported back to certain memories. The value of objects, Bachelard (1964) writes, is measured with their "degree of their association with memories and dreams." They also indicate "human values" when they are taken after (p. 70). He, in his essay Lamplight, approaches the "association of objects with memories and dreams." In doing so he argues that:

Whenever we live close to familiar, everyday things, we begin once again to live slowly, thanks to their fellowship, and so yield to dreams which have a past, yet in which there is always something fresh and new. The objects we store away in our treasure chest of things, in our small personal museum of beloved things, are all of them talismans of our dreams. We have only to evoke a much-loved object and its very name will set us dreaming of some ancient story. (Nojoumian 2006, p. 6)

Bachelard (1964) further argues that the house "shelters daydreaming", allowing one to "dream in peace." It also "holds childhood memories" and the values belonging to daydreaming "mark humanity in depths" (p. 6). It is commonly believed that our possessions might be utilized for delineating a "family tree." Dillon, however, is not much impressed by the "genealogist's labours." The inclination to trace one's family history by means of official documents seems as 'weird' to him as the "archival fever of those households" where "family snapshots are slipped into crackling albums, chronological depositories which assure the viewer of a frictionless unfolding of previous homes, notable occasions and beloved physiognomies" (Dillon 2005, p. 52). For him, objects transport him back to childhood. He is surrounded with things which "trace the most random pathways into the past" and at the same time make him "dispersed, fragmented among these relics" (p. 52). He also struggles to map them, but he finds himself unable to put them into a logical order. The small plastic 'snow-globe', for example, which used to be in the living room of Dillon's grandfather along with the things associated with it act as a 'memento' invoking strong recollections of the past especially those of his childhood holidays:

It partook of a modest and immediately decipherable narrative: it was a reminder of a place that somebody had visited. The place has vanished from my memory; I cannot summon the little landscape which the globe enclosed at all, nor the inscription which I am certain was to be read on its base. But the globe still conjures up the objects with which it was surrounded. Its smooth surface was dotted with condensation produced each morning by the competing water system of the steam from a kettle below. (p. 53)

As a further illustration, it is also true of the glass ashtray (as is the case with a lot of other objects in the house) which belonged to his father. The ashtray ceases to to be a mere thing any more and becomes a memento. It begins to indicate a world from which he had recently departed, being "the source of confusion" (p. 62) which might explain why he has kept it for all these years. This is also the moment when it stops being itself and starts to look unfamiliar and appears to say:

The world you think you remember is not as it seems. The recto surface of the memory is shadowed, like the glass itself, by its infinitely more complex verso. One side is smooth and reflective, the other jaggedly tactical, composing a nexus of memory images made up of the infinitely detailed patterning of things: a physical realm still sharp and clear beneath the compacted surface of ordinary recollection. The visible landscape of the memento, silted over with nostalgia, conceals the ancient and surprising geoloy of the object itself. (p. 62)

Bachelard claimed that houses and rooms could be employed for analyzing the human mind. Traditionally imagination is thought of as the faculty of forming images. For Bachelard (1964), 
however, imagination is the faculty of deforming images provided by perception being "the most natural of faculties" (p. 3). Man's capacity, he claims, to freely exercise his imagination is the basic measure of his mental health. Hospital is generally thought of as a place where patients are taken care of and cured. For Dillon, however, it symbolizes and denotes a place in which "humiliation and degradation" come into mind. There, when Dillon is about to visit his sick mother, he has no idea whether his mother is to kiss or embrace him:

It may have been after that particular visit that I came to fear the building itself. I no longer dared look at the patients around my mother, nor risk a glance through the open doors of the wards I passed on the way to hers. I ceased to think of a hospital as a place where you went to be cured; now it was a place where nameless forces sucked one in and thrust one out again looking weaker, less like oneself. The place became, as I got stuck in this childish perception, my most extreme metaphor of the inexplicable history that was unfolding around me. (Dillon 2005, p. 191)

Not only does the house but also the city and its streets function as a metaphor for evoking strong memories. Dillon feels so inclined to forget the area where he grew up, turning his head when "a bus from one side of the city to another came too close to one of the hospitals" (p. 161) where his mother had been a patient or worse, the hospital where she passed away, and even neglecting to visit his parents' grave, hoping to "map the city on a new scale," being "abstracted from the past" and at the same time "dotted with forgetful blanks". But he is constantly reminded of those sections of the picture he had "hoped to erase." They began seeping "through the overpainted surface" of his memory, leading to the "same district" (p. 161). Even transient memories of the city began to be aroused:

My habit of avoidance had seemed to accelerate to catch up with me, so that even more recent memories quickly became intolerable to me. Eventually, what had started as a strategy for avoiding the most haunted places in the city began to spread to the whole territory, so that in time I could hardly bear to be there at all. I recall a visit some years ago, having been away for a couple of years, when I found myself quite suddenly unable to walk the streets of Dublin without being overcome by a sense that every place was haunted by my previous life there. I hurried back to my new home convinced that I could never set foot in the city again. (Dillon 2005, p. 161)

"Every corner in a house", Bachelard (1964) contends, "every angle in a room, every inch of secluded place in which we like to hide, or withdraw into ourselves, is a symbol of solitude for the imagination; that is to say, it is the germ of a room, or of a house" (p. 136). This is the case with Dillon's family home. Before leaving the house for the last time, Dillon upon visiting different rooms catches up with diverse memories and his imagination is awaken being transformed into different stages in his life: "a specific sort of conduit from one room to another often exercised my childhood imagination" (Dillon 2005, p. 38). Or elsewhere regarding his father's ashtray, having stared at it long enough, Dillon places it in his imagination, "back in its proper home, hearing the sound of glass on wood, a sound that resounds both here and now on the desk in front of me and in distant recess of my memory" (p. 63). However, at some points Dillon gets sick and tired of the constant shifting in his mind between the present and the past, and the omnipresent memories associated with the objects in the house and endeavors to put them into the back of his mind:

But by now I am so tired of the house, so sick of its constant shuttling between past and present, so weary of the memories that are everywhere crammed into corners and drifting, untethered, across its floors, that I will gladly leave it to rot. The house, my mother had always insisted, was cursed. But the malediction, it turned out, was mine, and 
it was retrospective. I had simply never known how much I hated it, till the morning I abandoned it. (pp. 43-4).

Bachelard believes that when we daydream about things, for example a large forest full of tall trees we often exaggerate them in our minds to become immense and never ending. This exaggeration could be seen as man's efforts to make sense of the infinite nature of the universe. The house we were born in is "more than an embodiment of home." Bachelard (1964) argues that the house can be regarded as "an embodiment of dreams." All its different parts and rooms were a "resting-place for daydreaming. So there exists for "each one of us an oneiric house, a house of dream-memory, that is lost in the shadow of a beyond of the real past" (p. 15). Dillon, upon arriving at the hall, overcomes with a sense of stepping into the "still centre of the house" a place that is evocative of "more distant and serene memories", feeling "very small" as if he has "dropped into a sort of ravine" which reminds him of his "childhood perception of this spot" (Brian Dillon 2005, p. 23).

In the Production of Space, Henri Lefebrvi (1992) in his confirmation of Bachelard's new approach to the house believes that: "the house is as much cosmetic as it is human. A kind of "human space" to be inhabited and "once it is left empty, it suffers from solitude" (Nojoumian 2006, p. 4). After Dillon's mother dies, her sons find themselves stuck in these "ludicrous poses, like a photograph from which one figure has been erased with nothing to say to one another." The house also seemed to 'fracture' no longer enclosing a world, "however fraught, but a collection of discrete cells", places where, one would now always be recalled of something that had happened (Dillon 2005, p. 42). The narrator, therefore, makes an effort to demonstrate that "it is memory that controls him" as it accompanies him wherever in the house he steps into, and further that the family home, as a "repository of memory" becomes "truly alive once it has been vacated." No house, says Dillon (2005), "could be more comprehensively stocked with the detritus of the past than the empty house" (p. 29).

\section{Conclusion}

As observed and discussed above, the purpose of Brian Dillon's is to draw attention to the significance of the house and its objects. Doing so, he places a high value on spaces and possessions as tools whereby individuals are enabled to recall their most deeply buried memories. In another words, the house is wonderfully evocative of people' earliest recollections and feelings. The narrator of In the Dark Room is surrounded with objects which provide the opportunity for him to travel back in his mind to the past. Not only does the house function as a metaphor for evoking memories, but also the hospital in which his mother was taken care of is highlighted. Space, therefore, can be thought of as possessing human values and acts as a metaphor for human intimacy, dreams and solitude.

Gaston Bachelard is commonly associated with phenomenology which highlights the way phenomena appear to us and the manner they are given meaning. Therefore, the house and objects in it function as a place of intimacy and are are of great importance to him. The spaces along with objects are not merely possessions, but rather symbolize and suggest human soul. The house, writes Bachelard, supports the dreamer and provides him with the opportunity to dream in peace, and imagination and thought, as a result, are stimulated. Having read the abovementioned memoir within the framework of phenomenology and Bachelard's notions concerning house as a place of intimacy, we can consider "literature as a phenomenological reading of human life." In the Dark Room, says Wilson, is a "meditation on mourning and an excavation of memory" 
(p. 1). Dillon, he concludes, asks, "how does memory adheres to ashtrays and snow globes, stairwells and hallways? The answer is explored through the catastrophe of his family life" (p. 1).

\section{Works Cited}

Abrams, M. H. (2005). A Glossary of Literary Terms. Canada: Wadsworth Cengage Learning.

Bachelard, G. (1964). The Poetics of Space. Beacon Press Books.

Cazeaux, C. (2001). The Continental Aesthetics Reader. London and New York: Routledge.

Cuddon, J. A. (2013). A Dictionary of Literary Terms and Literary Theory. Wiley-Blackwell.

Dillon, B. (2005). In the Dark Room. Fitzcarraldo Editions.

Dillon's In the Dark Room. n. pag. web. 3 march 2020.

Lefebvre, H. (1992). The Production of Space. Trans. Donald Nickolson-Smith. Oxford:Blackwell.

Moran, D. (2000). Introduction to Phenomenology. London and New York: Routledge.

Nojoumian, A. A. ( 2006). Poetization of Space in One Hundred Years of Solitude. Journal of Pazhuhesh-e Zabanha-ye Khareji.

Payne, M., Barbera, J. R. (2010). A Dictionary of Cultural and Critical Theory. Wiley-Blackwell.

Hassan Abootalebi is currently studying at Kharazmi university, Tehran, Iran. His main areas of interest are postmodernism and metamodernism. He is also the author of numerous academic articles.

Alireza Kargar graduated in English language and literature from Lorestan university, Iran, and is the author of a number of academic articles. 